УДК 378

\title{
ДЕЯТЕЛЬНОСТЬ Д.С. ЛЬВОВА ПО УЛУЧШЕНИЮ КАЧЕСТВА ПОДГОТОВКИ И ПОВЫШЕНИЮ КВАЛИФИКАЦИИ СПЕЦИАЛИСТОВ В ОБЛАСТИ ЭКОНОМИКИ И УПРАВЛЕНИЯ
}

\author{
Рыбина Марина Николаевна \\ Быковская Екатерина Николаевна
}

к.э.н., доценты, доценты

ФГБОУ ВО «Государственный университет управления»

Аннотация: Наш соотечественник Д.С. Львов - выдающаяся личность рубежа XX-XXI вв. - экономист, академик Российской Академии Наук считал, что весь хозяйственный механизм должен быть развернут к человеку, направлен на первоочередное решение социальных проблем, при этом основная ставка должна быть сделана на высокий уровень образованности и профессиональной подготовки наших отечественных кадров. Академик четко обозначал приоритеты - наука, образование и здоровье населения.

Ключевые слова: новая экономика, нравственная экономика, образование и преподавание, социализация жизни, распределение природной ренты.

\section{D.S. LVOV'S ACTIVITY TO IMPROVE THE QUALITY OF TRAINING, RETRAINING AND ADVANCED TRAINING OF SPECIALISTS IN THE FIELD OF ECONOMICS AND MANAGEMENT}

\begin{abstract}
Our compatriot D.S. Lvov is an outstanding personality of the turn of the XX-XXI centuries. - economist, academician of the Russian Academy of Sciences believed that the entire economic mechanism should be deployed to a person, aimed at the priority solution of social problems, while the main bet should be made on a high level of education and professional training of our domestic personnel. The academician clearly outlined the priorities - science, education and health of the population.
\end{abstract}

Key words: new economy, moral economy, education and teaching , socialization of life, distribution of natural rent. 


\section{СОВРЕМЕННОЕ ОБРАЗОВАНИЕ: ОПЫТ ПРОШЛОГО, ВЗГЛЯД В БУДУЩЕЕ}

В конце XX века - начале XXI века Д.С. Львов (1930-2007) был известен российской общественности в связи с его блестящими выступлениями в средствах массовой информации. Его взгляды по широкому кругу социальноэкономического и политического развития новой России, проблем взаимосвязей между экономической эффективностью и социальной справедливостью, нравственной составляющей хозяйственной практики остаются актуальными и сегодня, а некоторые идеи злободневными и востребованными. Свою последнюю работу он назвал «Нравственная экономика»[1], этим названием, по сути, определив императив будущего социально-экономического развития России.

В 1954 году Д.С. Львов окончил машиностроительный факультет Московского инженерно-экономического института имени Серго Орджоникидзе. В 31 год защитил диссертацию на соискание ученой степени кандидата экономических наук. И с тех пор экономическая наука «не отпускала» ученого. В разные годы он работала в Институте экономики АН $\mathrm{CCCP,} \mathrm{в} \mathrm{Центральном} \mathrm{экономико-математическом} \mathrm{институте} \mathrm{РАН.}$ В Финансовом университете при Правительстве РФ он занимался научноисследовательской работой. Не прерывалась его связь с $\boldsymbol{A L M A ~ M A T E R}$ Государственным университетом управления. В своей деятельности ученого и просветителя он упорно с энтузиазмом и талантом оратора высказывался по злободневным вопросам развития страны настоящего для него времени, а также прописывал вектор развития России в будущем. Для этого академик использовал диалог с самым широким кругом своих соотечественников на телевидении, в периодической печати и в научных публикациях. Он использовал трибуну Ученых и Диссертационных советов в дискуссиях с коллегами и молодыми учеными, а также публичные лекции перед студентами. Академик Львов был выдающимся оратором. Глубина содержания его выступлений, публикаций, лекций отличалась метафоричностью и образностью языка - в них он использовал наглядные сравнения и параллели, выразительные эпитеты и юмор. Он умел завоевать внимание слушателей с первых слов оригинальностью подачи материала и удерживал это внимание до конца своего выступления. Перечисленные качества всех его выступлений в целом были полны глубокого смысла и касались самых насущных проблем современности и будущности нашего Отечества. Так, касаясь проводимых реформ, он писал о «шоковой пересадке в душу людей новых ценностей», а также о том, что Запад предложил нам 


\section{СОВРЕМЕННОЕ ОБРАЗОВАНИЕ: ОПЫТ ПРОШЛОГО, ВЗГЛЯД В БУДУЩЕЕ}

продукт отнюдь «не первой свежести» [2, с. 6]. Рассуждая о перспективах экономического развития страны, предлагал «оседлать» творческий фактор социально-экономического развития и предупреждал, что неэффективный труд может привести к «хирению» целых отраслей и территорий, вымиранию профессий, омертвлению национальных производительных сил в колоссальных масштабах. Он призывал вырвать россиян из «пагубного состояния» под названием «синдром вживания в катастрофу» [2, с. 24]. Показывая место России в международном разделении труда, считал, что «пришла пора перестать относиться к своей стране как к целине, которую нужно периодически поднимать и перепахивать заново, теряя всякий раз слои плодородной почвы, накопленной предшествовавшим развитием» [2, с. 8]. Академик предупреждал, что страна может оказаться «одним из главных фигурантов мирового подполья, угрожающего существованию, как самой России, так и всего мира» [1]. А так как, по его мнению, глобальная финансовая сеть «наброшена» на все страны мира, России нельзя «довольствоваться очередной ролью козла отпущения за мировой грех индустриальной и постиндустриальной цивилизации,... тем более, что разухабистые повороты новейшей российской истории преподнесли в последнее время так много новых загадок, что еще более размыли и без того расплывчатые очертания нашего возможного будущего» [ 2, с. 9]. Говоря о качестве жизни, о доходах населения, он подчеркивал, что в данном вопросе должны быть такие подходы, которые используются «в командной гонке велосипедистов, где зачет ведётся по последнему».

В начале двухтысячных годов по инициативе ректора ГУУ А.Г. Поршнева (1937-2008) и академика Д.С. Львова в Государственном университете управления был организован Институт новой экономики под научно-методическим руководством отделения экономики секции общественных наук РАН. Директором Института новой экономики стал академик Д. С. Львов. Целью создания такого института в рамках университета было развитие научно-образовательного потенциала вуза. Д.С. Львов возглавил Диссертационный совет в институте. Интеграция вуза с академической наукой дала положительные результаты в области анализа таких понятий и явлений как новая экономика, институционализация хозяйственных связей, место и роль государственного регулирования экономики. Проводились круглые столы и дискуссии по вопросам соотношения управления и менеджмента, давались ответы на актуальные 


\section{СОВРЕМЕННОЕ ОБРАЗОВАНИЕ: ОПЫТ ПРОШЛОГО, ВЗГЛЯД В БУДУЩЕЕ}

вопросы экономического развития страны в энергетической сфере, в области распределения природной ренты, места страны в глобальном мире. Эти мероприятия специалистов ИНЭ были нацелены на улучшение качества подготовки, переподготовки и повышения квалификации специалистов в области экономики и управления и опирались на передовые зарубежные и отечественные достижения, a также историю и традиции нашего отечественного образования. Он считал, что «долго еще Россия будет искать законченную форму социально-экономического и политического устройства. Цель будет уточняться в реальном движении. Смыслом этого движения должно стать заботливое освоение нашего национального опыта (включая семьдесят социалистических лет) и опыта мирового развития» [2, с.8]

За годы существования ИНЭ были проведены фундаментальные научные исследования по актуальным проблемам социально-экономического развития России и мировой экономики, которые нашли свое отражение почти в сотни диссертаций на соискание ученой степени кандидата экономических наук и были воплощены в практику хозяйственной деятельности страны. Авторами разного рода публикаций, монографий, учебников, научных докладов, аналитических записок стали привлеченные к работе в Институте новой экономики Д.С. Львовым такие ученые, как О.Т. Богомолов, С.Ю. Глазьев, А.Г. Гранберг, В.Е. Дементьев. В.В. Ивантер, Г.Б. Клейнер, В.И. Маевский, В.Л. Макаров, Н.Я. Петраков. Многие из них вошли в авторский коллектив одного из первых отечественных учебников по институциональной экономике. По мнению Д.С. Львова, коллектив ИНЭ был при призван смотреть в будущее и реализовывать новые подходы к оценке и выявлению сущности экономических процессов новой экономики. Генератором новых идей стал сам академик. Он обращался к тем, кто свое будущее не отделяет от будущего нашей России. С 2004 года в стенах Государственного университета управления начал проводится цикл публичных лекций «Академики РАН - студентам ГУУ». В свое время Д.С. Львов, определяя вектор диалога ученого сообщества со студентами и прописывая тем самым парадигму их научного поиска сформулировал, что «наиболее рельефно судьбы современного глобализирующегося мира отражают следующие проблемы:

- усиление социальной дифференциации стран и народов мира;

- сохранение национального многообразия народами мира ставятся выше экономических доктрин; 


\section{СОВРЕМЕННОЕ ОБРАЗОВАНИЕ:

- деградация природной среды, сопровождающаяся ростом крупных экологических катастроф;

- усиливающееся политическое противостояние стран;

- военные конфликты;

- международный терроризм;

- неконтролируемое распространение оружия массового уничтожения;

- резкое обострение проблем энергетической безопасности;

- кризис мировой финансовой системы и др.» [3]

Понятно, что возглавив Институт новой экономики, директору института Д.С. Львову было необходимо донести до ученого сообщества, студенчества и широкого общественного мнения, суть такого явления как новая экономика, а также содержание этого понятия. По его мнению, основные идеи теории новой экономики и ее исследования должны развиваться в следующих направлениях:

- новая экономика - явление противоречивое, в нем надо различать то, что уже в настоящее время его характеризует и то, за что надо «бороться» уже сейчас и в будущем;

- в новой экономике идет переоценка ценностей в сторону нравственного императива, в сторону выстраивания социалистического демократизма;

- важнейшую роль начинают играть нематериальные активы - знания, информация, наука, интеллектуальный потенциал;

- особой приметой становится усиливающаяся глобализация, причем процесс глобализации имеет пульсирующий и циклический характер; появляются новые институты регулирования и управления, в частности мировой экономикой. Вместе с тем сохранение национального многообразия должно быть поставлено выше любой экономической доктрины.

- возрастает и усиливается коллективистское начало, которое рождает необходимость доверия между хозяйствующими субъектами;

- происходит социализация жизни;

- в новой экономике необходимо обеспечение экологической устойчивости, новое общество - это общество эффективного взаимодействия Человека и Природы [1,2].

Если обратиться к его докладу «Россия: рамки реальности и контуры будущего», сделанному в ноябре 2006 года на заседании отделения экономики 


\section{СОВРЕМЕННОЕ ОБРАЗОВАНИЕ: ОПЫТ ПРОШЛОГО, ВЗГЛЯД В БУДУЩЕЕ}

секции общественных наук РАН, то мы увидим, что академик призывал основную ставку сделать «на высокий уровень образованности и профессиональной подготовки наших кадров. При этом весь хозяйственный механизм должен быть развернут к человеку, направлен на первоочередное решение социальных проблем. [3]. Привлечение притока молодежи в сферу НИОКР невозможно без «неукоснительного соблюдения законодательно установленного норматива на науку не ниже 3-4\% от общего объема бюджетных расходов» [2, с. 52]. Вместе с этим ученый предсказывал, что именно будущим специалистам необходимо будет реализовывать в жизнь отказ от сырьевой парадигмы и осуществлять перевод экономики России на рельсы научно-технического развития. Он призывал сосредоточиться на обеспечении конкурентоспособности отечественных товаров на мировом рынке, для чего считал необходимым ориентировать механизм управления на первоочередное развитие внутреннего рынка. Академик считал, что необходимо формирование опорного слоя нации. По его мнению - «это тот слой, для которого творчество и созидание являются исходной нормой жизни, а не только и не столько средством существования. В подлинном смысле слова - это Мастера:

$>$ создающие научные школы, передающие людям новые знания, обучающие их новым профессиям;

$>$ производители редких продуктов;

$>$ подвижники, поддерживающие и восстанавливающие здоровье людей;

$>$ хранители духовных и культурных ценностей народа;

$>$ работники, способные творить и созидать, а не только перераспределять уже накопленное» [2, с.19];

У Д.С. Львова было свое понимание будущности России. Суть этого понимания сводилась к следующему - «следует иметь в виду, что у магистрали, ведущей Россию в будущее, нет поворотов к советскому социализму. Но она не лежит на пути капитализма. В глобальном конфликте между Системой и Жизненном Миром человека Россия решительно должна стать на сторону последнего. А, следовательно, весь хозяйственный механизм должен быть развернут к человеку, направлен на первоочередное решение социальных проблем. Переход к Системе управления национальным имуществом, которая провозглашает освященный историей принцип: то, что в России от Бога, - должно принадлежать всем! А, следовательно, земля, 


\section{СОВРЕМЕННОЕ ОБРАЗОВАНИЕ: ОПЫТ ПРОШЛОГО, ВЗГЛЯД В БУДУЩЕЕ}

природные блага должны быть общественным достоянием. И каждый гражданин нашей страны, вне зависимости от национальной принадлежности, вероисповедания, политических взглядов, места проживания должен пользоваться правом равного доступа к тому, что в России от Бога, то есть к природному потенциалу России. А это приводит нас и к новой институциональной норме - право каждого на получение социального дивиденда. Огромная роль в решении этого вопроса отводится рентной системе налогообложения»[3].

Академик верил, что система образования в стране буде выстроена таким образом, что выпускники - управленцы настоящего и будущего не допустят серьезных провалов в экономике и в социальной сфере по причине их «непрофессионализма и отсутствия необходимых морально-нравственных качеств», как это случилось с теми, кому было доверено осуществление рыночных реформ [2, с. 7]. Итогом деятельности Д.С. Львова по улучшению качества подготовки и повышению квалификации специалистов в области экономики и управления стал существенный поворот управленческих структур разного уровня к осознанию глубокой сущности новой экономики, места России в ней в условиях неопределенности, в развивающемся циклически пульсирующем глобальном мире.

\section{Список литературы}

1. Львов Д.С. Нравственная экономика. - М.: Институт экономических стратегий, 2004. -44 с.

2. Львов Д.С. Будущее России: гражданский манифест. - М.: Волгоград: Издательство Волгоградского государственного университета, 2003. 72 с.

3. Львов Д.С. Россия: рамки реальности и контуры будущего.

Экономическая и философская газета, 2007, июль, № 29 (662)

4. Львов Д.С. Экономика развития. - М.: «Экзамен», 2002. - 512 с.

() М.Н. Рыбина, Е.Н. Быковская, 2021 